\title{
Late Asbian to Brigantian (Mississippian) foraminifera from southeast Ireland: comparison with northern England assemblages
}

\author{
IAN D. SOMERVILLE ${ }^{1} \&$ PEDRO CÓZAR ${ }^{2}$ \\ ${ }^{1}$ Department of Geology, University College Dublin, Belfield, Dublin 4, Ireland (e-mail: ian.somerville@ucd.ie) \\ ${ }^{2}$ UEI y Departamento de Paleontología, Facultad de Ciencias Geológicas, Instituto de Geología Económica CSIC-UCM, José Antonio Novais \\ 2, 28040 Madrid, Spain (e-mail: pcozar@geo.ucm.es)
}

\begin{abstract}
Foraminiferal assemblages from platform carbonates in the Carlow district (SE Ireland) are analysed. This platform contains a near-continuous succession of Upper Asbian to lower Upper Brigantian strata. Detailed sampling of several quarry and borehole sections allows characterization of foraminiferal assemblages throughout the succession. Assemblages typifying the Late Asbian, Early Brigantian and Late Brigantian are described, with the most common genera and species, as well as the guides for the recognition of these substages. In addition, three successive faunal events are recognized within the Early Brigantian. A comparison with northern England foraminiferal assemblages from the Asbian and Brigantian stratotype sections shows a great similarity in the recorded taxa. Furthermore, these taxa have closely comparable stratigraphical ranges, demonstrating the biostratigraphic utility of these foraminifera throughout Ireland and Britain. Taxa proposed here as guides for the basal Brigantian are potentially an alternative to the previously published taxa (which are either unrecorded, or recorded at higher stratigraphic levels in the Brigantian). J. Micropalaeontol. 24(2): 131-144, October, 2005.
\end{abstract}

KEYWORDS: Foraminifera, assemblages, Mississippian, SE Ireland, northern England

\section{INTRODUCTION}

In Britain and Ireland some of the best near-continuous successions across the Late Asbian/Brigantian boundary occur in northern England (Janny Wood section (Stainmore Trough; Strank, 1981), Yoredale 'Series' (Askrigg Block; Hallett, 1971) and Rookhope Borehole (Alston Block; Johnson \& Nudds, 1996)); in western Ireland (Aran Islands, Somerville, 1999; and the Burren area, Co. Clare, Gallagher, 1992) and in southern Ireland (Buttevant-Ballyclogh district, North Co. Cork, Gallagher, 1992; Gallagher \& Somerville, 1997; 2003). The sections in northern England were revised in Cózar \& Somerville (2004). The stratigraphic succession of the carbonate platform facies in southeastern Ireland is one of the more variable in Ireland and Great Britain. The succession has been studied in counties Carlow, Kilkenny and Laois (Fig. 1). A near-continuous record of the Upper Asbian to Brigantian rocks, which have been assigned to the Ballyadams and Clogrenan formations, occurs in this region (Tietzch-Tyler et al., 1994). These Upper Viséan limestones are unconformably overlain by 'Namurian' siliciclastic sediments. The Ballyadams and Clogrenan formations have been described recently in detail by Cózar \& Somerville (2005a, b), and six units were defined in the Carlow district, two units in the upper Ballyadams Formation and four in the overlying Clogrenan Formation (Fig. 2). This work is based mainly on the detailed analysis of seven quarries (including one natural section) and two boreholes (Figs. 1, 2): Ballyadams Quarry (divided into Ballyadams 1 and Ballyadams 2 sections; Irish Grid Reference (IGR) S 621916), Clogrenan B Borehole (IGR S 688720), Clogrenan Quarry (IGR S 688720), Bannagogle Quarry (IGR S 661645), Paulstown Quarry (IGR S 645602), Dunamase Quarry (IGR S 542993), Guileen-1 Borehole (IGR S 572915), Rock of Dunamase (IGR S 527973) (the latter is the only natural outcrop studied in the region) and Aghamaddock Quarry (IGR S 578945). These quarries and boreholes were sampled bed by bed, approximately at every metre, and a total of 1000 thin sections have been examined.

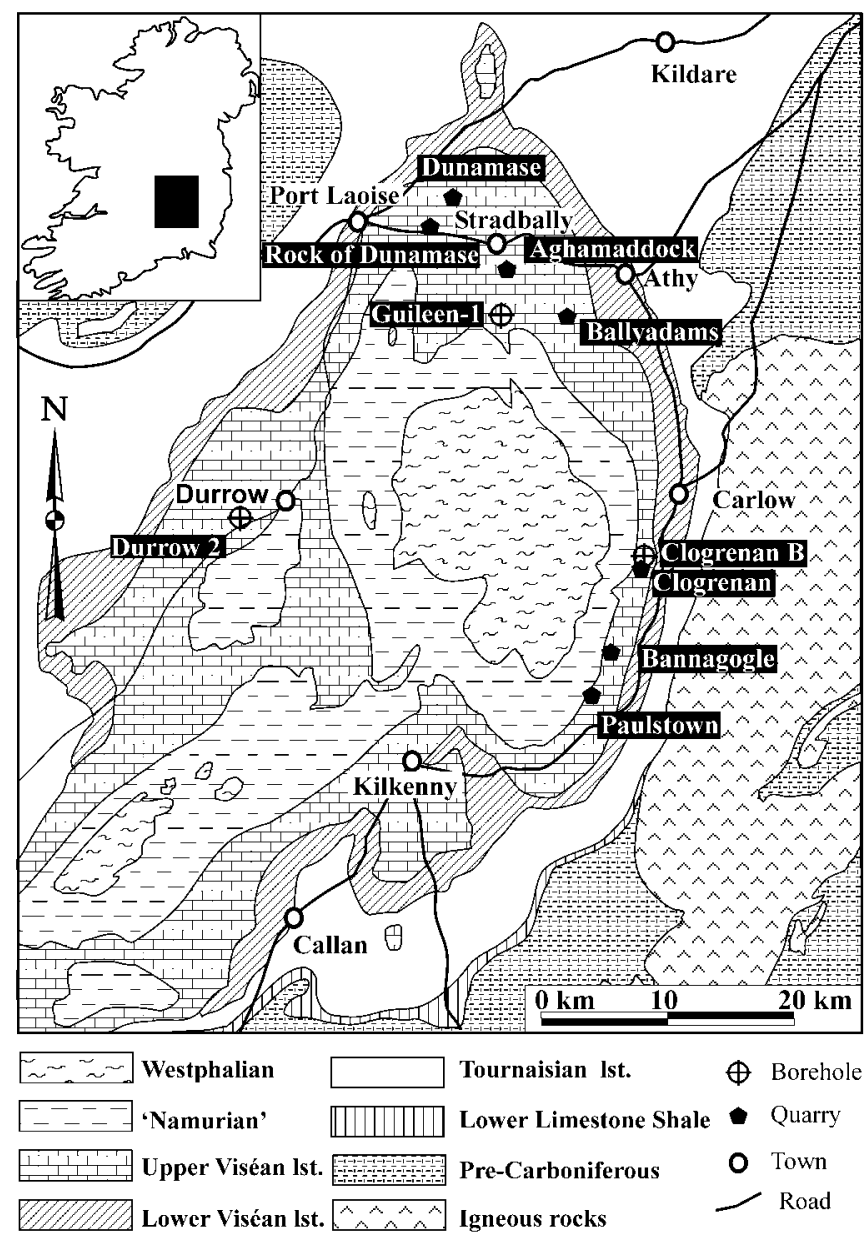

Fig. 1. Location of the studied quarries and boreholes. Irish grid of the sections mentioned in the text (modified from the GSI map, TietzchTyler et al., 1994). 
I. D. Somerville \& P. Cózar

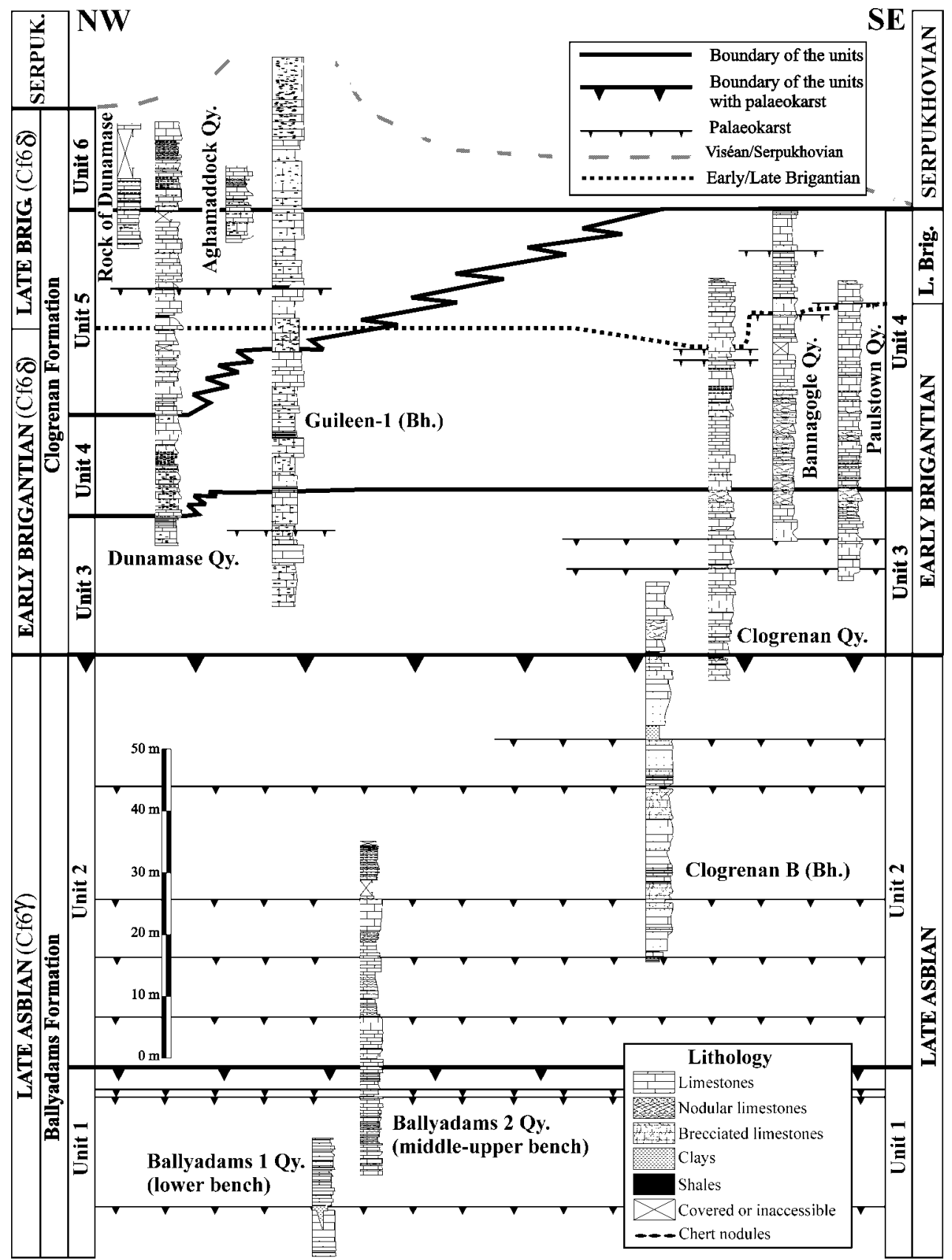

Fig. 2. Bio- and lithostratigraphical correlation in the Carlow district (modified from Cózar \& Somerville, 2005b).

The foraminiferal records from the Carlow district presented here represent a comprehensive database as a tool for comparison with other less well-exposed or discontinuous outcrops in Ireland. Moreover, some of the foraminiferal stratigraphic ranges documented in Ireland and Britain are revised, thereby increasing their utility for wider correlations with western Palaeotethyan basins. Biostratigraphically significant taxa are summarized in Figure 3 and illustrated in Plates 1 to 3. Species determinations of biostratigraphically less important taxa are simplified in most cases to open nomenclature, and listed in Appendix A. The suprageneric and familial classification of foraminifera used in this section follows the classification scheme described in Cózar (2003), modified from Vachard (1977), Conil et al. (1980), Loeblich \& Tappan (1988), RauzerChernousova et al. (1996), Pinard \& Mamet (1998) and Cózar \& Vachard (2001).

\section{TAXONOMIC REMARKS}

Three foraminiferal families (Archaediscidae, Palaeotextulariidae and Loeblichiidae) in the Upper Viséan warrant special mention, because they contain biostratigraphically important taxa, and a fourth family, the Tetrataxidae, contain taxa which have controversial assignations. Some primitive Archaediscidae are still present in these Upper Viséan sections, but the genus 
Mississippian foraminifera from SE Ireland

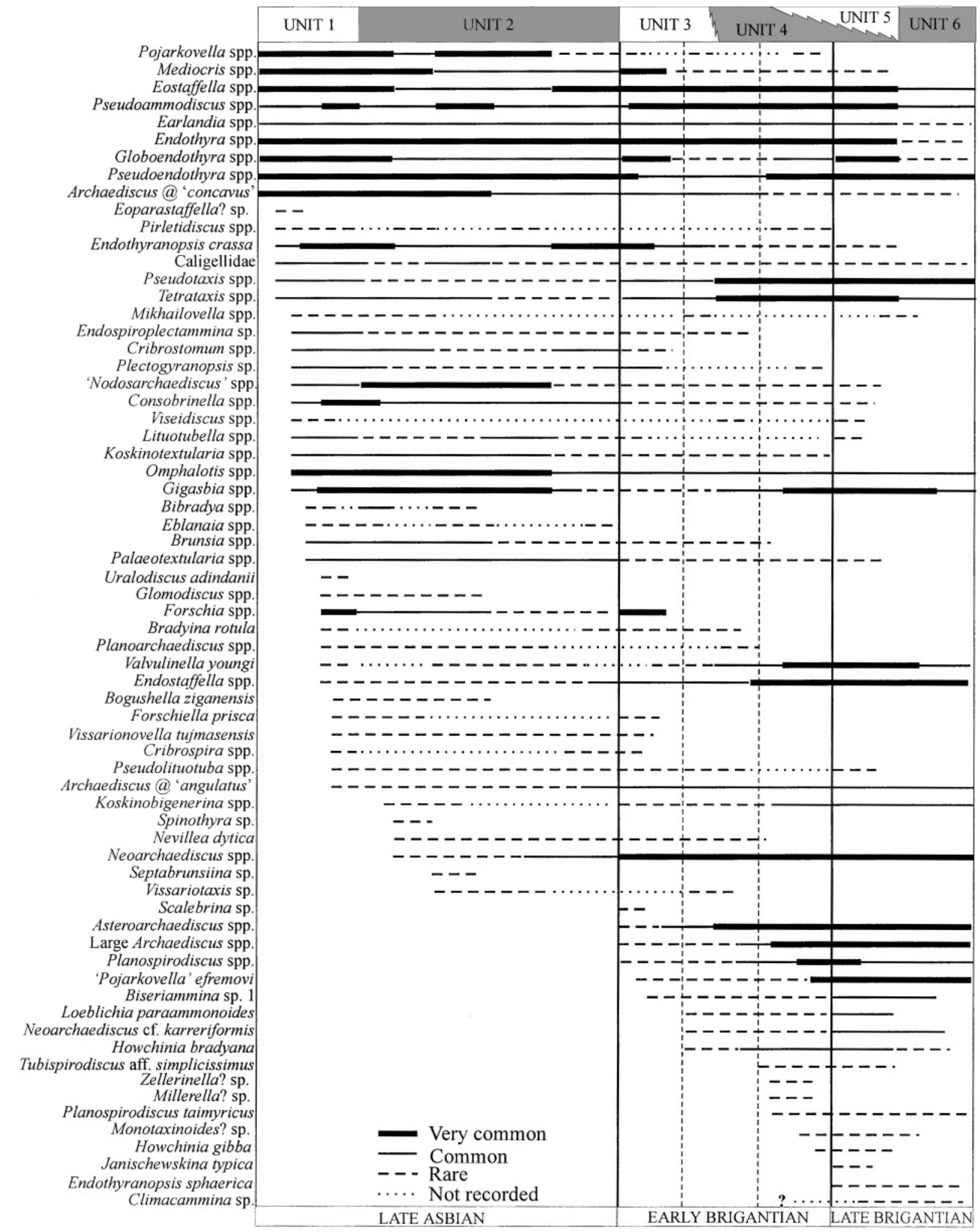

Fig. 3. Summary of the foraminiferal stratigraphic ranges in the Carlow district. Abbreviation: @, at stage. Rare, 1-2 specimens per thin section; common, 3-6 specimens per thin section; very common, $>6$ specimens per thin section. 


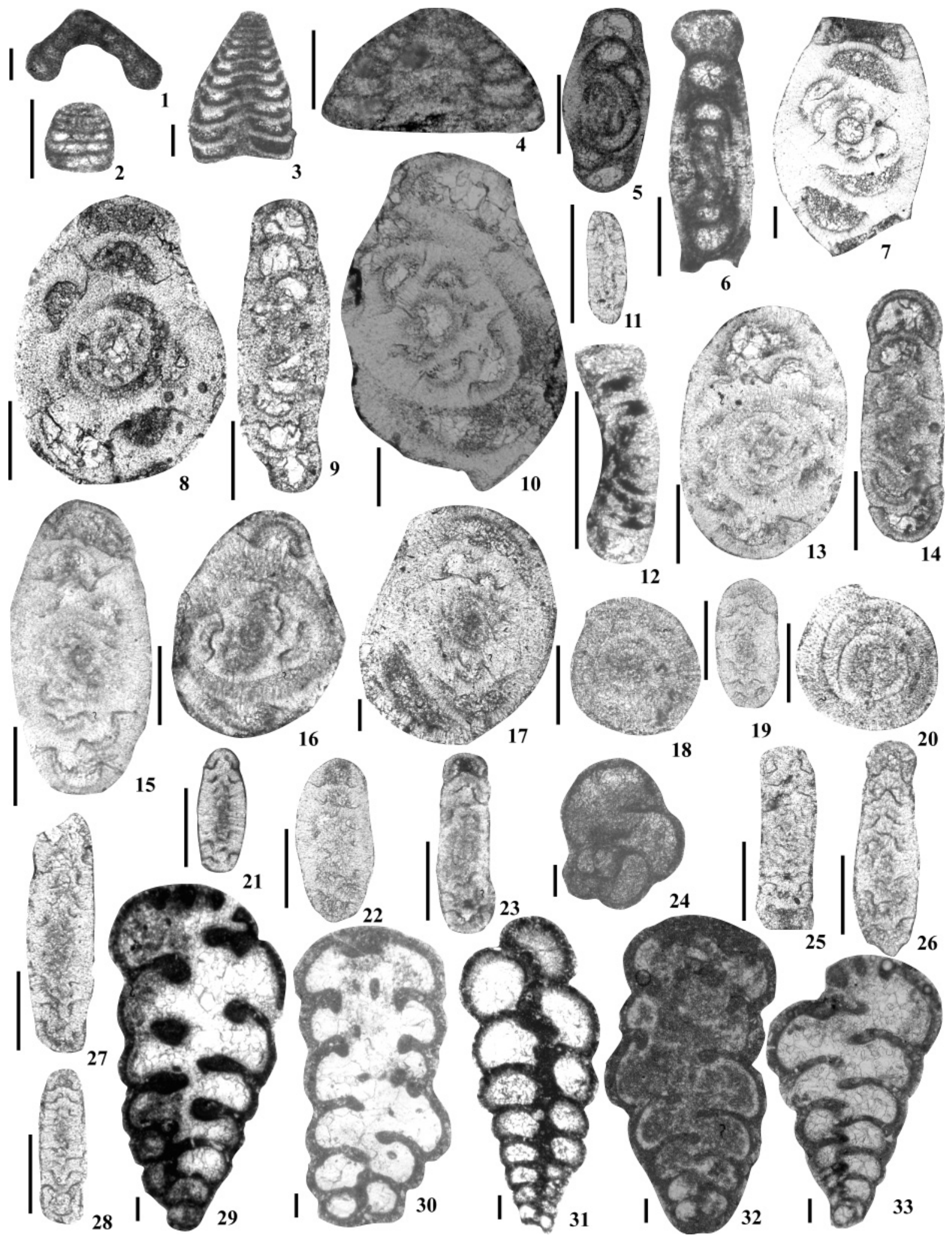


Archaediscus is highly diversified and many 'morphotypes' are recognized. However, specific taxonomic criteria are not very reliable and, thus, the validity of many of the species formally described is questioned (Zaninetti \& Altiner, 1979; Brenckle et al., 1987). Some authors have classified Archaediscus in species groups (e.g. Armstrong \& Mamet, 1977; Pinard \& Mamet, 1998), but even species groups do not seem to be representative of relative species and great differences are observed between specimens within the same group. As species and species groups of Archaediscus do not seem to be reliable enough for precision in the Carlow district, Archaediscus has been used exclusively as a function of its stage of evolution, based on Pirlet \& Conil (1977) and Conil et al. (1980). A special group within the 'angulatus' stage are the large Archaediscus, which include species such as $A$. karreri Brady and $A$. chernoussovensis Mamet. In the upper part of the Early Brigantian, and mostly in the Late Brigantian, some Archaediscus at 'angulatus' stage exhibit 2-2.5 totally evolute final whorls, but tapering at the base of the lumina is not conspicuous. True Archaediscus at 'tenuis' stage (=Betpakodiscus auct.) are not recorded in the Carlow district, but they are occasionally recorded in northeastern Ireland in the latest Brigantian (Poulmore Scarp, Kingscourt, Co. Meath; unpublished data).

The stellate archaediscids (Asteroarchaediscinae in Appendix A) are also common and, in fact, they are more common in the Brigantian than the Archaediscus that are without occlusion of the lumina. The Upper Asbian rocks contain numerous 'Nodosarchaediscus' spp., but they occur up to the Late Brigantian (Fig. 3). The validity of this genus is controversial (see Vachard, 1988; Pinard \& Mamet, 1998) and some authors do not recognize the presence of 'nodes' as having morphological distinction (Brenckle et al., 1987; Brenckle \& Grelecki, 1993). As none of the classification schemes for Archaediscidae are universally accepted, for the time being, all the specimens possessing nodes are referred to as 'Nodosarchaediscus', some of them at 'concavus' stage and others at 'angulatus' stage. The most evolved Neoarchaediscus is $N$. cf. karreriformis (Reitlinger). The validity of the species is also controversial, because the holotype is not well orientated (see Brenckle \& Grelecki, 1993). This taxon exhibits large tests, more than $400-500 \mu \mathrm{m}$, a sigmoidal coiling and more than 2.5 occluded whorls. $N$. cf. karreriformis occurs always in the middle part of the Early Brigantian and, locally, it can be very common in the Late Brigantian (Fig. 3).

The Palaeotextulariidae are represented widely and many genera and species occur (see Appendix A). However, despite the presence of numerous specimens of palaeotextulariids in thin sections, well-orientated adult specimens are scarce. As a consequence, the database of palaeotextulariid assemblages is impoverished, as specific determinations are often impossible. Some genera of single-layered wall palaeotextulariids documented in the British literature, such as Palaeobigenerina and Deckerella (e.g. Hallett, 1971; White, in Johnson \& Nudds, 1996), have not been recognized, but their presence in Upper Viséan rocks seems to be unlikely and they are probably guides for the Bashkirian (Pinard \& Mamet, 1998).

In the Tetrataxidae, the validity of Pseudotaxis eominima (type species of the genus) and, therefore, of the genus Pseudotaxis Mamet 1974a, is still in a state of flux. Some authors considered the genus Endotaxis Bogush \& Brazhnikova in Aizenverg et al. (1983) to be valid (and, hence, Pseudotaxis invalid), with the type species E. brazhnikovae (e.g. Groves, 1988), whereas other authors consider E. brazhnikovae synonymous with P. eominima (Vachard \& Beckary, 1991; Pinard \& Mamet, 1998; Cózar, 2003). In addition, some workers considered both taxa valid (e.g. White in Johnson \& Nudds, 1996). Here, E. brazhnikovae is regarded as synonymous with $P$. eominima.

The Loeblichiidae are represented mostly by Pojarkovella spp., including $P$. nibelis (Durkina). The genus is very common in the Asbian (Fig. 3) and, usually, thin sections contain

\section{Explanation of Plate 1.}

Selected Lasiodiscidae, Archaediscidae, Biseriamminidae and Palaeotextulariidae from the Carlow district. In all plates the species name is followed by the thin-section sample number, stratigraphic section (quarry, unless a named borehole), horizon (these were documented in Cózar \& Somerville, 2005b) and limestone unit (see Fig. 2) (scale bar $100 \mu \mathrm{m}$, except for figs 29-33, where scale bar $150 \mu \mathrm{m}$; all the thin sections are housed in the Department of Palaeontology Madrid, UCM): 1, cf. 'Monotaxinoides' sp., DPM-PC-1269, Dunamase, horizon 25 (unit 5); 2, Vissariotaxis sp., DPM-PC-27/8/93, Ballyadams 2, horizon 61 (unit 2); 3, Howchinia bradyana (Howchin) emend. Davis, DPM-PC-944, Clogrenan, horizon 55 (unit 3); 4, Howchinia gibba (von Moeller), DPM-PC-20/8/24, Paulstown, horizon 20 (unit 4); 5, Glomodiscus rigens (Conil \& Lys), DPM-PC-27/8/85, Ballyadams 2, horizon 53 (unit 2); 6, Uralodiscus adindanii Brenckle \& Marchant, DPM-PC-27/8/25, Ballyadams 1, horizon 30 (unit 1); 7, Archaediscus chernoussovensis Mamet, DPM-PC-1430, Dunamase, horizon - 5 (unit 3); 8, Archaediscus karreri grandis Conil \& Lys, DPM-PC-8/ 8/71, Clogrenan, horizon 58 (unit 4); 9, Archaediscus at 'angulatus' stage (Archaediscus krestovnikovi Rauzer-Chernousova), DPM-PC-8/8/72, Clogrenan, horizon 59 (unit 3); 10, 'Nodosarchaediscus' convexus (Grozdilova \& Lebedeva), DPM-PC-9/8/7, Bannagogle, horizon 2 (unit 3); 11, Tubispirodiscus aff. simplicissimus Browne \& Pohl, DPM-PC-24/9-2/25, Dunamase, horizon 16 (unit 4); 12, Tubispirodiscus aff. simplicissimus Browne \& Pohl, DPM-PC-24/9-2/25, Dunamase, horizon 16 (unit 4); 13, Neoarchaediscus occlusus (Hallett), DPM-PC-8/8/45, Clogrenan, horizon 40 (unit 4); 14, Neoarchaediscus parvus (Rauzer-Chernousova), DPM-PC-8/8/66, Clogrenan, horizon 54 (unit 4); 15, Neoarchaediscus regularis (Suleimanov), DPM-PC-8/8/36, Clogrenan, horizon 33 (unit 3); 16, Neoarchaediscus ovoides (Rauzer-Chernousova), DPM-PC-8/8/44, Clogrenan, horizon 39 (unit 4); 17, Neoarchaediscus cf. karreriformis (Reitlinger), DPM-PC-1286, Dunamase, horizon 43 (unit 5); 18, Neoarchaediscus subbaschkiricus (Reitlinger), DPM-PC-1335, Clogrenan B Borehole, horizon 5 (unit 2); 19, Asteroarchaediscus rugosus (Rauzer-Chernousova), DPM-PC-20/8/12, Paulstown, horizon 8 (unit 3); 20, Asteroarchaediscus baschkiricus (Krestovnikov \& Theodorovich), DPM-PC-9/8/15, Bannagogle, horizon 7 (unit 3); 21, Planospirodiscus aff. taimyricus Sossipatrova, DPM-PC-8/8/52, Clogrenan, horizon 45 (unit 4); 22, Neoarchaediscus incertus (Grozdilova \& Lebedeva), DPM-PC-20/8/1, Paulstown, horizon 1 (unit 3); 23, Neoarchaediscus aff. borealis (Reitlinger), DPM-PC-8/8/59, Clogrenan, horizon 50 (unit 4); 24, Biseriammina sp. 1, DPM-PC-24/9-2/65, Dunamase, horizon 54 (unit 6); 25, Planospirodiscus minimus (Grozdilova \& Lebedeva), DPM-PC-1386, Guileen-1 Borehole, horizon 8 (unit 4); 26, Planospirodiscus gregorii (Dain), DPM-PC-1373, Clogrenan, horizon 9 (unit 3); 27, Planospirodiscus cf. gregorii (Dain), DPM-PC-1273, Dunamase, horizon 28 (unit 5); 28, Planospirodiscus taimyricus Sossipatrova, DPM-PC-24/92/74, Dunamase, horizon 62 (unit 6); 29, Cribrostomum lecomptei Conil \& Lys, DPM-PC-27/8/36, Ballyadams 2, horizon 10 (unit 1); 30, Koskinobigenerina prisca (Lipina), DPM-PC-8/8/36, Clogrenan, horizon 33 (unit 3); 31, Palaeotextularia longiseptata Vissarionova, DPM-PC-27/8/ 31, Ballyadams 2, horizon 5 (unit 1); 32, Climacammina sp., DPM-PC-1448, Aghamaddock, horizon 17 (unit 6); 33, Koskinotextularia cribriformis Eickhoff, DPM-PC-27/8/43, Ballyadams 2, horizon 18 (unit 1). 


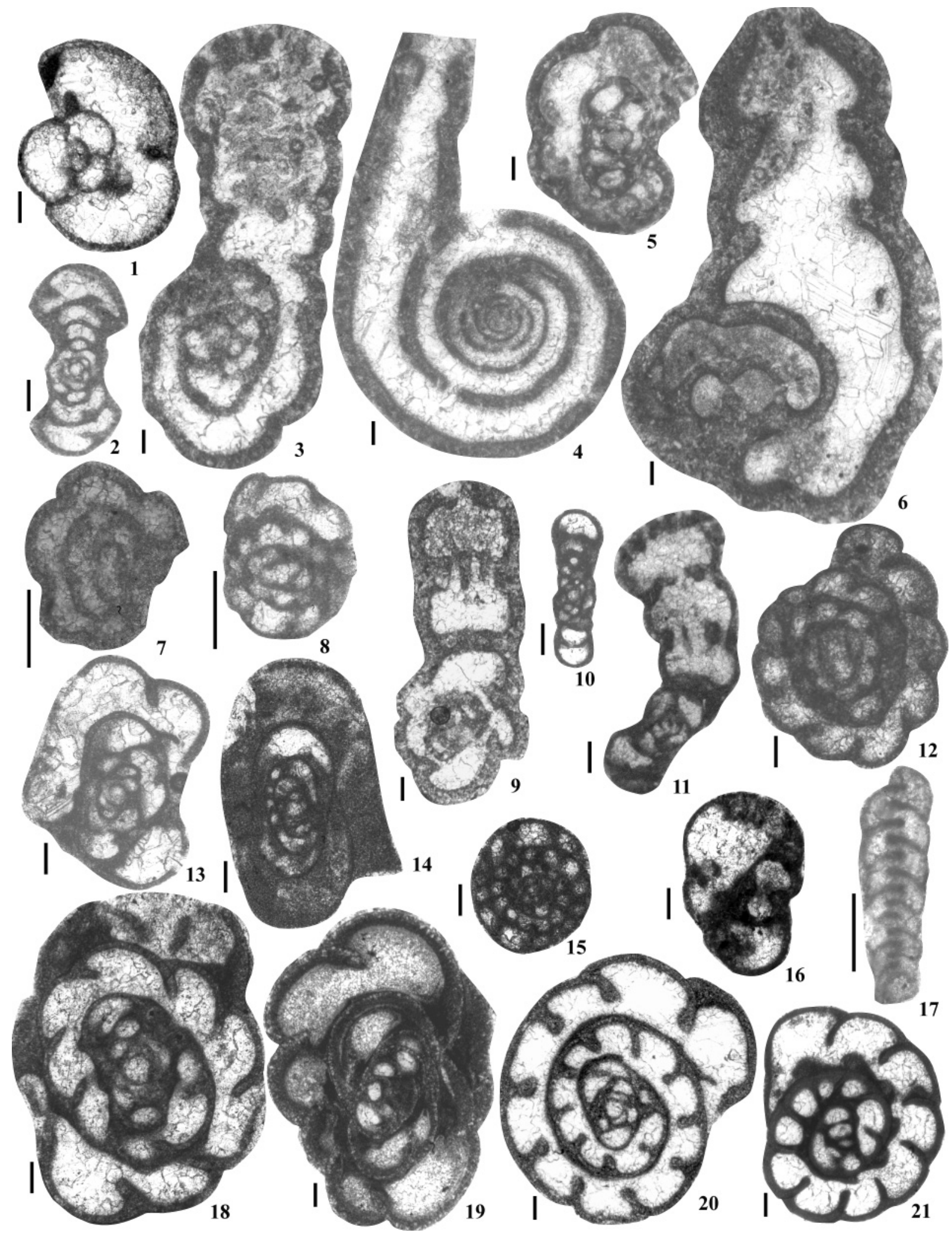


numerous specimens, up to 60 per thin section. This genus is actually poorly known, despite numerous documentations in the literature, and the presence of the luminotheca in the wall is a variable character (Cózar, 2002). There are several species included within the genus, mostly from Russian localities (see revision in Cózar, 2002) but, as shown by Strank (1981), the genus shows many morphological variations in Great Britain. Strank (1981) distinguished P. nibelis (Durkina) and five species in open nomenclature. A revision of the species included in the genus in Great Britain and Ireland is necessary. 'Pojarkovella' efremovi (Vdovenko \& Rostovceva) is a very common Brigantian taxon, mostly in the Late Brigantian, with tens of specimens per thin section. Its presence in the Late Asbian in western Palaeotethyan basins is occasional (Laloux, 1988; Cózar \& Somerville, 2004). This taxon shows development of chomata, a partial development of an outer darker microgranular layer in the wall, a progressive deflection in the coiling axis, rounded external periphery of the whorls and rarely, a granular wall. Similar specimens were illustrated by Conil et al. (1980) as Endostaffella parva (pl. 22, figs 20-22), in the Brigantian of the Archerbeck Borehole, Scotland. Endostaffella exhibits a rapid change in the final two whorls, which are almost planispiral, and is clearly evolute. Moreover, the size of 'Pojarkovella' is larger than in the Endostaffella. On the other hand, these specimens could be determined as being included in the genus Plectostaffella, commonly documented in Britain and Ireland (Conil et al., 1980; Strank, 1981; Gallagher, 1992). However, these Plectostaffella are problematical; some of the illustrated specimens are interpreted here as pathologies in Eostaffella (e.g. in Gallagher \& Somerville, 1997), a second group of Plectostaffella show only slight deflections in the initial coiling axis of Eostaffella (e.g. in Conil et al., 1980; Strank, 1981) and a third group are interpreted here as oblique sections of the second group (e.g. in Conil et al., 1980). Additionally, it can be stated that true Plectostaffella first occur in the Late Serpukhovian and Bashkirian (Mamet, 1974b; Groves, 1983; Vachard \& Maslov, 1996), together with true Eostaffellina. In a separate study, Reitlinger (1981) placed Euxinita in synonymy with Pojarkovella, but Pinard \& Mamet (1998) did not accept this synonymy, because they considered Euxinita as a smaller genus characterized by a well-differentiated wall. However, as demonstrated by Cózar (2002), there are species of Pojarkovella with and without well-developed luminotheca, as well as species with poorly- and well-developed outer tectoria. Thus, Cózar (2002) concluded that the presence of this differentiation in the wall is not a very reliable character for generic or specific taxonomy in this group. Here, in the Carlow district, similar features are observed: there are rare specimens with an 'undifferentiated' wall and a 'luminotheca', and many specimens with an outer tectoria.

\section{BIOZONATION OF THE CARLOW DISTRICT}

The Late Asbian in Ireland was divided into two subzones: Cf6 $\gamma 1$ and Cf6 $\gamma 2$ (Gallagher, 1996; Jones \& Somerville, 1996; Gallagher \& Somerville, 1997). The guides for the lower subdivision $(\mathrm{Cf} 6 \gamma 1)$ were the first appearance of Cribrostomum lecomptei, Bibradya grandis and Cribrospira spp.; guides for the upper subdivision $(\mathrm{Cf} 6 \gamma 2)$ were the first appearance of Howchinia bradyana (rare, and only at the top), Bradyina rotula, Neoarchaediscus stellatus, Neoarchaediscus incertus, Saccamminopsis sp., along with the algae Fasciella kizilia (rare) and Koninckopora sp. B. The first occurrence of Cribrostomum lecomptei, Bibradya grandis and Cribrospira spp. is in unit 1 (Ballyadams Quarry). Bradyina rotula is also recorded in Ballyadams 1 (unit 1), near the base of the succession in the Carlow district (Figs 2, 3). However, in much of the Ballyadams Quarry section Bradyina rotula, Bibradya and Cribrospira are rare or unrecorded (Fig. 3). Howchinia bradyana and the algal problematicum Saccamminopsis, on the other hand, first occur $15 \mathrm{~m}$ and $5 \mathrm{~m}$ (respectively) above the Asbian/Brigantian boundary (unit 3), and Neoarchaediscus occurs approximately in the middle part of Ballyadams 2 (unit 2, Fig. 3). The algal problematicum Fasciella kizilia is recorded in the middle part of unit 1, and the alga Koninckopora sp. B in the upper part of unit 2 (Cózar \& Somerville, 2005a). Thus, the stratigraphic ranges of some of the taxa are not in full agreement with the proposed scheme. Nevertheless, the presence of common Neoarchaediscus, together with Bradyina rotula and Cribrospira panderi, suggest the top of the Ballyadams Quarry and the upper part of Clogrenan B Borehole are assignable to an uppermost Late Asbian, Cf6 $\gamma 2$ Subzone. This is further supported by the presence of Koninckopora sp. B, only known at this level (Somerville et al., 1992; Gallagher \& Somerville, 1997), and the marked concentration of Gigasbia gigas, 'Nodosarchaediscus', Pojarkovella and Endothyranopsis crassa (Fig. 3). However, an extension down of this subzone to the base of Ballyadams Quarry (where Bradyina and Fasciella occur) is uncertain.

Explanation of Plate 2.

Selected Tournayellidae, Forschiniidae, Dainellidae and Endothyridae (pars) from the Carlow district (scale bar $100 \mu \mathrm{m}$, except for figs $2-6$ and 19-21 where scale bar $150 \mu \mathrm{m}$ ): 1, Spinothyra sp., DPM-PC-27/8/44, Ballyadams 2, horizon 20 (unit 1); 2, Septabrunsiina sp. 1, DPM-PC-1128, Ballyadams 2, horizon 1 (unit 1); 3, Lituotubella glomospiroides Rauzer-Chernousova, DPM-PC-27/8/73, Ballyadams 2, horizon 48 (unit 1); 4, Forschiella prisca (Mikhailov), DPM-PC-27/8/70, Ballyadams 2, horizon 47 (unit 2); 5, Bogushella ziganensis (Grozdilova \& Lebedeva), DPM-PC-27/8/40, Ballyadams 2, horizon 13 (unit 1); 6, Lituotubella magna Rauzer-Chernousova, DPM-PC-1142, Ballyadams 2, horizon 15 (unit 1); 7, Septabrunsiina sp. 2, DPM-PC-1321, Clogrenan B Borehole, horizon 3 (unit 2); 8, Septabrunsiina sp. 1, DPM-PC-27/8/15, Ballyadams 1, horizon 18 (unit 1); 9, Nevillea dytica (Conil \& Lys), specimen number DPM-PC-27/8/104, Ballyadams 2, horizon 71 (unit 2); 10, Septabrunsiina sp. 2, DPM-PC-27/8/80, Ballyadams 2, horizon 51 (unit 2); 11, Mikhailovella gracilis (Rauzer-Chernousova), DPM-PC-27/8/15, Ballyadams 1, horizon 18 (unit 1); 12, Eblanaia michoti (Conil \& Lys), DPM-PC-1321, Clogrenan B Borehole, horizon 3 (unit 2); 13, Eblanaia sp., DPM-PC-27/8/27, Ballyadams 2, horizon 1 (unit 1); 14, Vissarionovella tujmasensis (Vissarionova), DPM-PC-1320, Clogrenan B Borehole, horizon 2 (unit 2); 15, Vissarionovella tujmasensis (Vissarionova), DPM-PC-1326, Clogrenan B Borehole, horizon 5 (unit 2); 16, Bibradya sp., DPM-PC-1181, Ballyadams 2, horizon 51 (unit 2); 17, Endospiroplectammina sp. 1, DPM-PC-27/8/1, Ballyadams 1, horizon 1 (unit 1); 18, Globoendothyra sp., DPM-PC-27/8/62, Ballyadams 2, horizon 36 (unit 1); 19, Globoendothyra ex gr. globulus (d'Eichwald), DPM-PC-27/8/25, Ballyadams 1, horizon 30 (unit 1); 20, Globoendothyra globulus (d'Eichwald), DPM-PC-27/8/58, Ballyadams 2, horizon 33 (unit 1); 21, Omphalotis omphalota (Rauzer-Chernousova \& Reitlinger), DPM-PC-27/8/43, Ballyadams 2, horizon 18 (unit 1). 


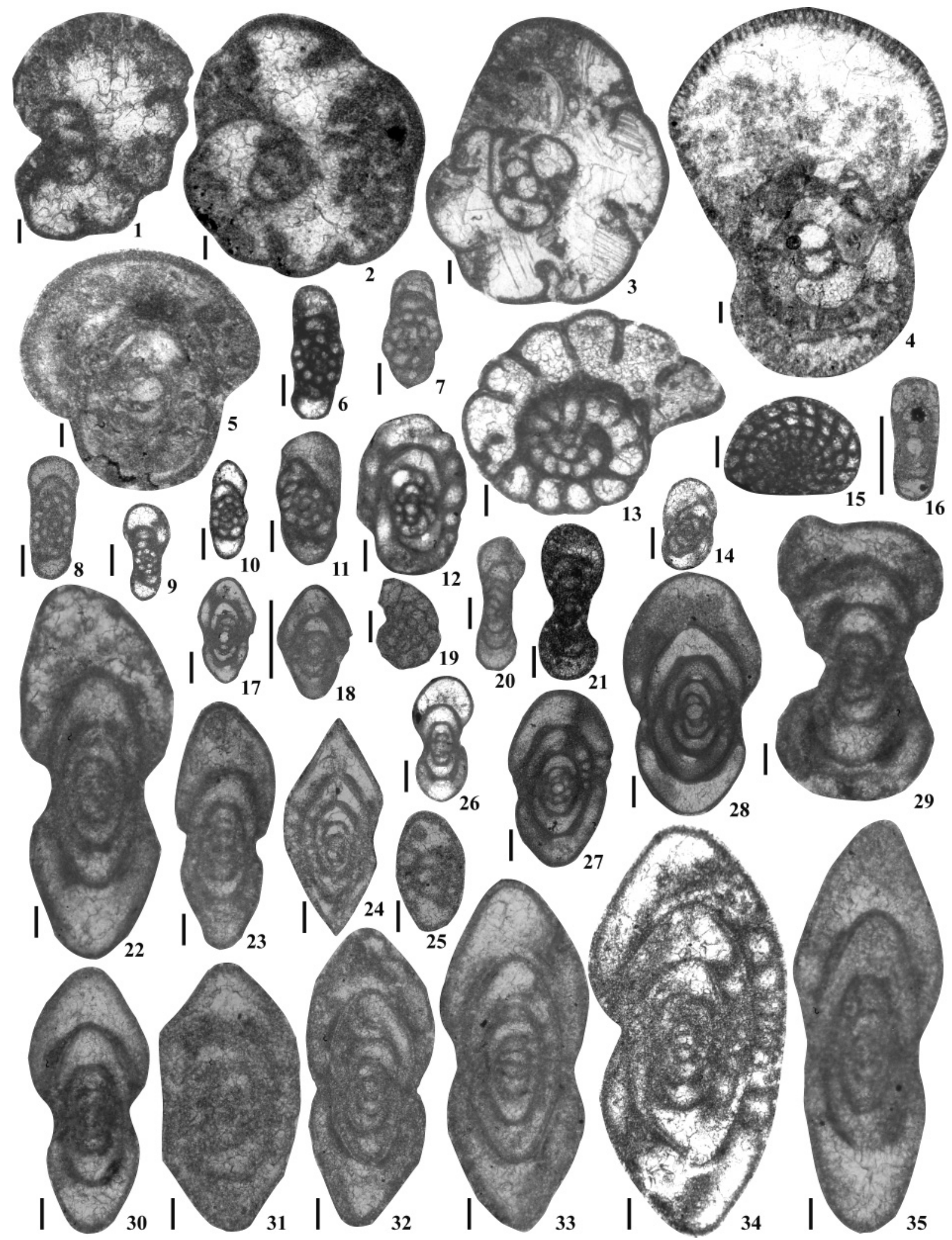


The Early Brigantian (Cf6 $\delta$ Subzone) foraminiferal distribution seems to be the result of two main factors: biostratigraphical changes and facies control. Facies control is a significant factor, because laterally equivalent units (upper part of unit 4 in SE Carlow and unit 5 in NW Carlow, Fig. 2) exhibit distinct assemblages, compositionally, as well as in the number of specimens. Moreover, a change between units 3 and 4 is lithologically conspicuous, but is also highlighted by distinct foraminiferal assemblages (both in composition, as well as in the number of specimens). Thus, three distinct assemblages are recognized in the Early Brigantian (Fig. 3).

The first assemblage (from the base of unit 3 and the base of the Early Brigantian) is characterized by the first occurrence of Asteroarchaediscus, Planospirodiscus and large Archaediscus at 'angulatus' stage (e.g. A. karreri) from the base, and at higher levels in the assemblage, 'Pojarkovella' efremovi and Biseriammina sp. 1, all of which are rare. Many typical Asbian taxa last occur, mostly Forschiidae (Forschia and Forschiella), Dainellidae (Vissarionovella) and 'Endothyra' ex gr. prisca. Moreover, many other taxa are recorded very rarely, e.g. Lituotubella, Endospiroplectammina, Cribrospira, most species of Pojarkovella and Brunsia, or show a significant decrease in the number of specimens per thin section, e.g. 'Nodosarchaediscus' spp. and most species of Palaeotextulariidae. The primitive Neoarchaediscus are common. A comparable suite of foraminifera characterize the Early Brigantian Liscarrol Limestone Formation in North Co. Cork in which stellate archaediscids and Neoarchaediscus are abundant, as well as large archaediscids of the A. karreri group (Gallagher, 1992; Gallagher \& Somerville, 1997).

The second assemblage (uppermost part of unit 3 to the lower part of unit 4; Figs 2,3) is characterized by the first occurrence of rare Howchinia bradyana, Neoarchaediscus cf. karreriformis and Loeblichia paraammonoides. Neoarchaediscus are common and the last occurrence of Nevillea dytica, Bradyina rotula and Vissariotaxis are recorded.
The third assemblage (the middle part of unit 4 and the lower part of unit 5 in the NW area; Figs 2, 3) is characterized by the first occurrence of rare Tubispirodiscus aff. simplicissimus, Howchinia gibba and Planospirodiscus taimyricus. 'Pojarkovella' efremovi and Biseriammina sp. 1 are also rare, although the former taxon can be very common locally. Moreover, there are common to very common Howchinia bradyana, Asteroarchaediscus and Neoarchaediscus. Two striking taxa recorded in this interval are Millerella? sp. and Zellerinella? sp. Both taxa do not extend higher in the succession and, thus, their biostratigraphical significance for interbasinal correlations in Ireland and Britain remains rather limited. However, their occurrences are relevant, because true Millerella is only recorded from the upper part of the early Serpukhovian (Arnsbergian) (Groves, 1983; 1988; Vachard \& Maslov, 1996; Armstrong \& Mamet, 1977; Pinard \& Mamet, 1998) and most species of Millerella recorded by authors (e.g. Conil et al., 1980; Strank, 1981), were transferred into the genera Eostaffella, Zellerinella, or Pseudoendothyra (e.g. Armstrong \& Mamet, 1977). Similar specimens, questionably assigned to Millerella were recognized in northern England (Cózar \& Somerville, 2004), but from the Pendleian Great Limestone. On the other hand, Zellerinella is a typical taxon of the North American Chesterian Stage (Upper Mississippian) and, thus, its occurrence in the Brigantian of the Carlow district agrees with its stratigraphic range in North American basins. However, Zellerinella is currently considered to be an endemic taxon of North America and South Asia (Pinard \& Mamet, 1998) and possibly also in the Russian basins.

The guides for the Late Brigantian assemblages are the first occurrence of rare Climacammina, Janischewskina typica, Endothyranopsis sphaerica, as well as common large Archaediscus at 'angulatus' stage, Neoarchaediscus, Asteroarchaediscus, Neoarchaediscus cf. karreriformis, Biseriammina sp. 1 and 'Pojarkovella' efremovi. Climacammina occurs in the uppermost part of the succession in Dunamase and Aghamaddock quarries (Fig. 2). However, there is a specimen of questionable determination from unit 4 in Paulstown Quarry (Figs 2, 3). This

Explanation of Plate 3.

Selected Endothyridae (pars), Endostaffellidae, Loeblichiidae, Eostaffellidae and Pseudoendothyridae from the Carlow district (scale bar $100 \mu \mathrm{m}$, except for figs 1-5 where scale bar $150 \mu \mathrm{m}$ ): 1, Bibradya grandis Strank, DPM-PC-1314, Clogrenan B Borehole, horizon 2 (unit 2); 2, Cribrospira panderi (von Moeller), DPM-PC-1340, Clogrenan B Borehole, horizon 7 (unit 2); 3, Janischewskina typica Mikhailov, DPM-PC-24/9-2/40, Dunamase, horizon 28 (unit 5); 4, Bradyina rotula (d'Eichwald), DPM-PC-953, Bannagogle, horizon 2 (unit 3); 5, Endothyranopsis sphaerica (Rauzer-Chernousova \& Reitlinger), DPM-PC-1307, Dunamase, horizon 62 (unit 6); 6, Endostaffella shamordini (Rauzer-Chernousova), DPM-PC27/8/42, Ballyadams 2, horizon 17 (unit 1); 7, Endostaffella parva (Moeller), DPM-PC-27/8/36, Ballyadams 2, horizon 10 (unit 1); 8, Endostaffella? sp., DPM-PC-20/8/24, Paulstown, horizon 20 (unit 4); 9, Endostaffella sp. 1, DPM-PC-881, Clogrenan, horizon 5 (unit 3); 10, Endostaffella shamordini (Rauzer-Chernousova), DPM-PC-1379, Guileen-1 Borehole, horizon 4 (unit 3); 11, Endostaffella aff. parva (Moeller), DPM-PC-27/8/36, Ballyadams 2, horizon 10 (unit 1); 12, 'Pojarkovella' efremovi (Vdovenko \& Rostovceva), DPM-PC-8/8/11, Clogrenan, horizon 15 (unit 3); 13, Pojarkovella sp. 2, DPM-PC-27/8/1, Ballyadams 1, horizon 1 (unit 1); 14,'Pojarkovella' efremovi (Vdovenko \& Rostovceva), DPM-PC-20/8/31, Paulstown, horizon 25 (unit 4); 15, Loeblichia paraammonoides Brazhnikova, DPM-PC-1397, Guileen-1 Borehole, horizon 18 (unit 5); 16, Mediocris sp. 1,DPM-PC-8/8/32, Clogrenan, horizon 31 (unit 3); 17, Eostaffella radiata (Brady), DPM-PC-9/8/15, Bannagogle, horizon 7 (unit 3); 18, Eostaffella ex gr. proikensis Rauzer-Chernousova, DPM-PC-8/8/37, Clogrenan, horizon 34 (unit 4); 19, Zellerinella? sp., DPM-PC-8/8/52, Clogrenan, horizon 45 (unit 4); 20, Zellerinella? sp., DPM-PC-8/8/52, Clogrenan, horizon 45 (unit 4); 21, Millerella? sp., DPM-PC-8/8/43, Clogrenan, horizon 39 (unit 4); 22, Eostaffella sp. 2, DPM-PC-1335, Clogrenan B Borehole, horizon 5 (unit 2); 23, Eostaffella sp. 1, DPM-PC-1347, Clogrenan B Borehole, horizon 12 (unit 2); 24, Eostaffella ex gr. ikensis Vissarionova, DPM-PC-24/9-2/24, Dunamase, horizon 15 (unit 4); 25, Eostaffella ex gr. parastruvei Rauzer-Chernousova, DPM-PC-8/8/9, Clogrenan, horizon 13 (unit 3); 26, Eoparastaffella? sp., PC1617, Ballyadams 1, horizon -3 (unit 1); 27, Eostaffella mosquensis Vissarionova, DPM-PC-1434, Dunamase, horizon - 4 (unit 3); 28, Eostaffella parastruvei Rauzer-Chernousova, DPM-PC-1432, Dunamase, horizon -3 (unit 3); 29, Eostaffella sp. 3 (E. parastruvei group), DPM-PC-1337, Clogrenan B, horizon 7 (unit 2); 30, Pseudoendothyra ornata (Brady), DPM-PC-1337, Clogrenan B Borehole, horizon 7 (unit 2); 31, Pseudoendothyra kremenskensis Rozovskaya, DPM-PC-1316, Clogrenan B Borehole, horizon 2 (unit 2); 32, Pseudoendothyra sublimis (Schlykova), DPM-PC-1369, Clogrenan B Borehole, horizon 2 (unit 3); 33, Pseudoendothyra sublimis (Schlykova), DPM-PC-8/8/11, Clogrenan, horizon 15 (unit 3); 34, Pseudoendothyra bona Rozovskaya, DPM-PC-9/8/39, Bannagogle, horizon 26 (unit 3); 35, Pseudoendothyra aff. nodus (Durkina), DPM-PC-1333, Clogrenan B Borehole, horizon 5 (unit 2). 
specimen appears to be a transitional form between Cribrostomum and Climacammina, because the uniserial arrangement of the chambers is not well developed or, alternatively, it could be a juvenile of Climacammina. Janischewskina typica (=J. operculata auct.) is only recorded in Upper Brigantian rocks in England and Ireland. However, Strank (1981) recorded Janischewskina delicata from the basal Brigantian Peghorn Limestone in northern England. As documented by Conil et al. (1980, p. 83, pl. 19, fig. 11; pl. 26, figs 13-14), the latter species and other specimens recorded in the Late Brigantian part of the Archerbeck Borehole and the Petershill Limestone, Scotland, exhibit a distinct 'alveolar'-like septum wall in the final chambers and, thus, their inclusion in the genus Janischewskina is debatable. Cózar \& Somerville (2004) referred to these specimens as Janischewskina? spp. No other specimens belonging to Janischewskina? spp. are recorded anywhere else in Ireland.

\section{COMPARISON WITH NORTHERN ENGLAND FORAMINIFERAL ASSEMBLAGES}

Similar genera and species of Pseudolituotubidae are recorded in both the SE Ireland and northern England successions (Cózar \& Somerville, 2004), but they are more common in the latter. However, these genera are also common in SW Ireland (Gallagher, 1996). Thus, the poor assemblages in Pseudolituotubidae in the Carlow district are interpreted as a local phenomenon. In addition, Conil et al. (1980) recorded a greater assemblage of Pseudolituotubidae in a more extensive geographical area in Britain, although its Brigantian marker, Warnantella, has not been recorded by the authors in Ireland, nor in northern England.

Vissariotaxis, one of the typical basal Asbian markers (e.g. Conil et al., 1991), is very rare in the Carlow district (only four specimens have been recorded) and, in the sections from northern England revised by Cózar \& Somerville (2004), only one specimen was recorded - from the Gordale Limestone in the Back Scar Borehole. In Little Asby Scar (Basal Asbian Stratotype), the first occurrence of Vissariotaxis is $13.3 \mathrm{~m}$ above the base (only in one thin section; Ramsbottom, 1981; Strank, 1981). Despite this though, there is still a general consensus about the validity of Vissariotaxis as a basal Asbian marker. In marked contrast is the occurrence of Vissariotaxis in other basins, such as the Guadiato Area, SW Spain (Cózar, 2003), in which many thin sections of Late Asbian rocks (c. 50\%) contain one or two specimens and often up to five specimens.

As was mentioned previously, the first occurrence of Howchinia bradyana was used by Jones \& Somerville (1996) and Gallagher (1996) to define the uppermost Late Asbian or Cf6 $\gamma 2$ division, although in North Co. Cork it does not first appear until Cf6 $\delta$ Subzone, $30 \mathrm{~m}$ above the base of the Brigantian (Gallagher \& Somerville, 1997). In the Carlow district, $H$. bradyana is first recorded in the upper part of unit 3 (only one specimen) and more commonly from the base of unit 4 (Fig. 3). Thus, its first occurrence is about $25 \mathrm{~m}$ above the base of the Brigantian. In the shallow-water platform facies in the Alston and Askrigg blocks (northern England), Howchinia bradyana is occasionally recorded in the lower part of the Brigantian and it is common above the Smiddy Limestone (Cózar \& Somerville, 2004). However, in the slightly deeper-water platform facies in the Stainmore Trough, H. bradyana first occurs from the Late
Asbian Knipe Scar Limestone and it is common from the Peghorn Limestone (Basal Brigantian limestone, according to George et al., 1976) (Fig. 4). However, as Cózar \& Somerville (2004) demonstrated, algae and foraminifera in the Janny Wood section (Basal Brigantian Stratotype in the Stainmore Trough), do not correlate precisely with the fauna and flora recorded in shallower-water facies of the adjacent Alston and Askrigg blocks. Algal and foraminiferal taxa, together with brachiopod and coral data, suggest that the Robinson or Birkdale limestones could be considered as Brigantian in age and, thus, before a detailed revision of the Brigantian Stratotype is undertaken, comparison of the fauna in the Janny Wood section with other outcrops in England or Ireland is inappropriate for the moment. On the other hand, in the middle part of the Early Brigantian in northern England, Howchinia gibba (Moeller) first occurs and becomes common at the top of the Early Brigantian. This species is recorded very rarely in the Carlow district in the upper part of the Early Brigantian and base of the Late Brigantian (Fig. 4), but it is unrecorded in SW Ireland. However, it is common in the Brigantian in NE Ireland (Carganamuck Quarry, Co. Armagh and Poulmore Scarp, Kingscourt, Co. Meath; unpublished data).

Most Archaediscidae exhibit similar stratigraphic ranges in England and Ireland, except for Asteroarchaediscus and Planospirodiscus (Fig. 4). These genera are excellent basal Brigantian markers in Ireland but, in northern England, they first occur at the top of the Early Brigantian (Strank, 1981; Cózar \& Somerville, 2004). In addition, Planospirodiscus taimyricus is known only from the 'Namurian' in northern England, much later than in Ireland. Also notable, is the absence of Tubispirodiscus aff. simplicissimus in the Brigantian from northern England; it is known only from the Yeadonian (Upper 'Namurian' =Pennsylvanian) (Fewtrell et al. 1981, pl. 3.12, fig. 20, as Neoarchaediscus incertus).

The Palaeotextulariidae also exhibit similar stratigraphic ranges in England and Ireland, with Climacammina, recorded only in the Late Brigantian, for which it can be considered as a useful marker.

Among the Tournayellidae, the absence of 'Tournayellina' can be highlighted in the Carlow district. This is a genus known in other districts in Ireland (Somerville et al., 1992; Gallagher, 1996; Somerville, 1999) and also recorded commonly in northern England from the Robinson Limestone and higher levels (Cózar \& Somerville, 2004).

Biseriammina sp. 1 has been recorded in the Carlow district, as well as in the Kingscourt district, Co. Meath and Cookstown, Northern Ireland (unpublished data), but does not occur in northern England (Cózar \& Somerville, 2004). However, the distribution of Biseriammina is not restricted to Ireland because this taxon occurs also in Belgium (Laloux 1988, as Globispiroplectammina). This distribution suggests an incomplete knowledge of its occurrences and possibly a misidentification with Biseriella in other basins. However, Biseriella parva (Chernysheva) has not been recorded in the Carlow district, yet the genus is known from the Late Brigantian in England (Fig. 4).

Janischewskina typica is recorded only in Upper Brigantian rocks in England and Ireland. However, no other specimen of Janischewskina? spp. (recorded in the Early Brigantian Peghorn Limestone in Janny Wood section and the Archerbeck 


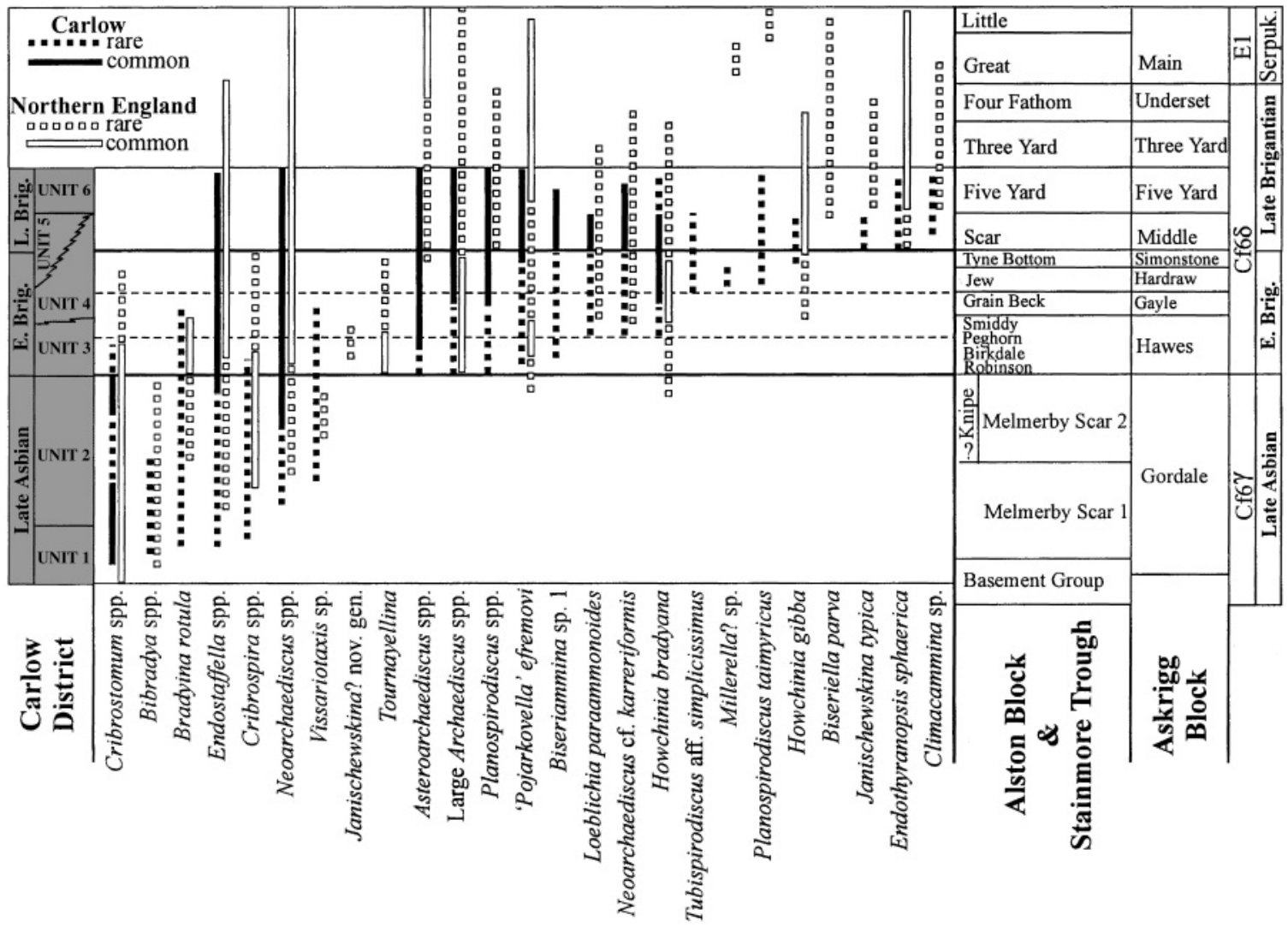

Fig. 4. A comparison of the stratigraphical ranges of the key foraminiferal taxa in the Carlow district and northern England (modified from Cózar \& Somerville, 2004). Abbreviations: E. Brig., Early Brigantian; L. Brig., Late Brigantian; Serpuk., Serpukhovian.

Borehole and Petershill Limestone, Scotland) is known by the authors.

The Loeblichiidae, Eostaffellidae and Pseudoendothyridae also exhibit similar stratigraphic ranges in England and Ireland.

A summary of the stratigraphically significant genera and species is shown in Figure 4. Most of the taxa have the same distribution in Ireland and northern England (Fig. 4). The exceptions are the absent species in the Carlow district, such as Janischewskina? nov. gen., Biseriella parva and 'Tournayellina'. In addition, Asteroarchaediscus, Planospirodiscus taimyricus and Tubispirodiscus have first occurrences earlier in Ireland. The diversity and abundance of the assemblages of northern England and the Carlow district are also different, e.g. in the Pseudolituotubidae.

Other data described by Cózar \& Somerville (2004) from northern England, regarding the stratigraphical range of typical basal Brigantian markers (Loeblichia, Janischewskina and Warnantella according to Conil et al., 1991), suggest that they do not occur at the base of this stage (e.g. Loeblichia), or occur only in the Late Brigantian (e.g. Janischewskina), or are absent (e.g. Warnantella) in Ireland. Alternative basal Brigantian markers for Ireland are considered here to include: Asteroarchaediscus, large Archaediscus, Planospirodiscus, 'Pojarkovella' efremovi and Biseriammina sp. 1. Basal Late Brigantian guides include: Endothyranopsis sphaerica, Climacammina and Janischewskina typica. Nevertheless, the acmes of 'Pojarkovella' efremovi, Biseriammina sp. 1, Neoarchaediscus cf. karreriformis and Planospirodiscus taimyricus are considered here to be restricted primarily to the Late Brigantian.

\section{CONCLUSIONS}

The foraminifera of shallow-water platform carbonates from the Asbian to Brigantian strata of the Carlow district have been examined. The typical Late Asbian assemblages are dominated by Pojarkovella nibelis, Mediocris, Eostaffella ex gr. radiata, E. ex gr. proikensis, Pseudoendothyra ex gr. ornata, P. ex gr. bona, Endothyra, Globoendothyra, Archaediscus at 'concavus' stage, Pseudotaxis micra, Omphalotis and Gigasbia, associated with the other typical markers such as Bibradya, Cribrospira panderi, Bradyina rotula, Endothyranopsis crassa and Cribrostomum lecomptei (Fig. 3).

The Early Brigantian assemblages are dominated by Eostaffella ex gr. parastruvei, E. ex gr. mosquensis, Pseudoammodiscus, Endothyra (with common E. ex gr. phrissa and E. ex gr. spira), Globoendothyra (G. globulus), Pseudotaxis eominima, Tetrataxis, Omphalotis omphalota, Valvulinella youngi, Endostaffella, Archaediscus at 'angulatus' stage, Neoarchaediscus and Howchinia bradyana, with the other important markers: Asteroarchaediscus, large Archaediscus, Planospirodiscus, 'Pojarkovella' efremovi and Biseriammina sp. 1 (Fig. 3).

The Late Brigantian assemblages are dominated by Eostaffella ex gr. parastruvei, E. ex gr. mosquensis, Pseudoendothyra sublimis, Pseudotaxis eominima, Tetrataxis, Omphalotis omphalota, Gigasbia gigas, Endostaffella, Valvulinella, 
Neoarchaediscus, Asteroarchaediscus, large Archaediscus, Planospirodiscus, 'Pojarkovella' efremovi, Biseriammina sp. 1 and Neoarchaediscus cf. karreriformis, associated with the markers Endothyranopsis sphaerica, Climacammina and Janischewskina typica (Fig. 3).

The recognition of these three distinct foraminiferal assemblages in the Late Asbian, Early Brigantian and Late Brigantian from shallow-water platform limestones in SE Ireland has been made in other parts of Ireland and also, especially, within the well-documented sections in northern England, including the stratotype sections for the Asbian and Brigantian stages in the British Isles. Although the Asbian type section at Little Asby Scar is in a carbonate-dominant sequence, comparable to the Ballyadams Formation in SE Ireland, the Brigantian stratotype section at Janny Wood is in a mixed siliciclastic-carbonate sequence, unlike the mainly limestonerich Clogrenan Formation in SE Ireland. The cyclothemic sequences (Yoredale facies) in northern England contain thick shallow-marine limestone beds developed throughout the Alston and Askrigg blocks, representing widespread transgressive events (see Burgess \& Mitchell, 1976; George et al., 1976; Johnson \& Nudds, 1996). Many of the diagnostic Brigantian foraminiferal taxa in this region are also recorded in SE Ireland (except for those in the upper Late Brigantian interval, which is absent) and they also have comparable stratigraphic ranges (see Cózar \& Somerville, 2004). However, because of the difficulties in identifying the previously distinguished foraminiferal taxa for the basal Brigantian (see Fewtrell et al., 1981; Strank, 1981; Strank in Ramsbottom, 1981), several different taxa which characterize the Early Brigantian substage have been proposed. They include: large Archaediscus, Asteroarchaediscus, Planospirodiscus, 'Pojarkovella' efremovi and Biseriammina sp. 1.

In the type Viséan section in Belgium, the Upper Viséan (Warnantian) is incomplete, with most of the upper Warnantian (=Brigantian) strata very thin (Laloux, 1988). As such, it is impossible to make detailed comparisons of the foraminiferal assemblages from the Belgian sections with those in SE Ireland and northern England.

\section{ACKNOWLEDGEMENTS}

The authors would like to thank Demir Altiner and Stephen Gallagher for reviewing the manuscript.

\section{List of identified species within families (subfamilies)}

1. Earlandiidae: Earlandia clavatula (Howchin), E. elegans (Rauzer-Chernousova \& Reitlinger), E. moderata Malakhova, E. minima Birina, Earlandia spp., Gigasbia gigas Strank, and Gigasbia spp.

2. Pseudoammodiscidae: Brunsia pseudopulchra (Lipina) and B. spirillinoides (Grozdilova \& Glebovskaya), Pseudoammodiscus priscus (Rauzer-Chernousova), $P$. volgensis (Rauzer-Chernousova), and Pseudoammodiscus spp.

3. Caligellidae: Ademasa inucta Vachard, Baituganella chernyshinensis Lipina, Protoinsolentitheca fundamenta Vachard \& Cózar and Protoinsolentitheca serpuchoviensis (Brazhnikova).

4. Pseudolituotubidae: Pseudolituotuba sp. 1, Pseudolituotuba gravata (Conil \& Lys), and Scalebrina sp. 1.
5. Lasiodiscidae: Howchinia bradyana (Howchin) emend. Davis, Howchinia gibba (von Moeller), Monotaxinoides? sp. and Vissariotaxis sp. (poorly orientated specimens, probably $V$. compressa Brazhnikova).

6. Archaediscidae

(a) (Archaediscinae): Archaediscus at 'concavus' stage, Archaediscus at 'angulatus' stage, large Archaediscus at 'angulatus' stage (A. karreri Brady, A. chernoussovensis Mamet, A. gigas, A. krestovnikovi Rauzer-Chernousova groups), Glomodiscus rigens (Conil \& Lys), Planoarchaediscus spirillinoides (Rauzer-Chernousova), Planoarchaediscus spp., Pirletidiscus? sp. 1, Tubispirodiscus aff. simplicissimus Browne \& Pohl emend. Vachard, Uralodiscus adindanii Brenckle \& Marchant, Viseidiscus monstratus (Rauzer-Chernousova).

(b) (Asteroarchaediscinae): Asteroarchaediscus baschkiricus (Krestovnikov \& Theodorovich), A. rugosus (RauzerChernousova), Neoarchaediscus incertus (Grozdilova \& Lebedeva), N. ovoides (Rauzer-Chernousova), N. occlusus (Hallett), N. stellatus (Bozorgnia), N. parvus (Rauzer-Chernousova), N. regularis (Suleimanov), $N$. probatus (Reitlinger), N. timanicus (Reitlinger), Neoarchaediscus spp., N. subbaschkiricus (Reitlinger), N. aff. borealis (Reitlinger), $N$. cf. karreriformis (RauzerChernousova), 'Nodosarchaediscus' demaneti (Conil \& Lys), 'N.' convexus (Grozdilova \& Lebedeva), 'Nodosarchaediscus' spp., Planospirodiscus minimus (Grozdilova \& Lebedeva), P. gregorii (Dain), P. aff. gregorii (Dain), and $P$. aff. taimyricus Sossipatrova, Planospirodiscus taimyricus Sossipatrova.

7. Palaeotextulariidae: Climacammina sp., Consobrinella minima (Lipina), C. consobrina (Lipina), Consobrinella spp., Cribrostomum lecomptei Conil \& Lys, Koskinotextularia cribriformis Eickhoff, Koskinobigenerina prisca (Lipina), Palaeotextularia longiseptata Vissarionova and Palaeotextularia spp.

8. Tetrataxidae: Pseudotaxis micra Conil \& Longerstaey, $P$. eominima (Rauzer-Chernousova), Tetrataxis conica Ehrenberg, Tetrataxis spp., Valvulinella youngi (Brady).

9. Tournayellidae: Bogushella ziganensis (Grozdilova \& Lebedeva), Eblanaia michoti (Conil \& Lys), Septabrunsiina sp. 1, S. sp. 2, Spinothyra sp.

10. Forschiidae: Forschia mikhailovi Dain, F. parvula (RauzerChernousova), Forschiella prisca (Mikhailov), Lituotubella glomospiroides Rauzer-Chernousova, L. magna RauzerChernousova, and Nevillea dytica Conil \& Lys.

11. Biseriamminidae: Biseriammina sp. 1.

12. Dainellidae: Vissarionovella tujmasensis (Vissarionova).

13. Endothyridae: Bibradya grandis Strank, Bibradya inflata Strank, Bradyina rotula (Eichwald), Cribrospira panderi von Moeller, Cribrospira spp., 'Endothyra' ex gr. prisca Rauzer-Chernousova \& Reitlinger (=Priscella auct.), Endothyra ex gr. similis Rauzer-Chernousova \& Reitlinger, Endothyra ex gr. bowmani Phillips emend. China, Endothyra ex gr. spira Conil \& Lys, Endothyra ex gr. phrissa RauzerChernousova, Endothyranopsis compressa (RauzerChernousova), E. crassa (Brady), E. sphaerica (RauzerChernousova \& Reitlinger), Endospiroplectammina sp. 1, Globoendothyra globulus (Eichwald), Globoendothyra sp. 1, 
Mikhailovella gracilis caledonae Conil \& Longerstaey, Janischewskina typica Mikhailov [=J. operculata (RauzerChernousova \& Reitlinger)], Mikhailovella gracilis RauzerChernousova, Omphalotis minima (Rauzer-Chernousova \& Reitlinger), O. omphalota (Rauzer-Chernousova \& Reitlinger), Plectogyranopsis convexa (Rauzer-Chernousova), $P$. ampla (Conil \& Lys), P. settlensis Conil \& Longerstaey, and P. hirosei (Okimura) sensu Mamet et al. (1993).

14. Endostaffellidae: Endostaffella parva (Moeller), E. shamordini (Rauzer-Chernousova), Mediocris mediocris (Vissarionova), M. breviscula (Ganelina), Mediocris sp. 1.

15. Loeblichiidae: Loeblichia paraammonoides Brazhnikova, 'Pojarkovella' efremovi (Vdovenko \& Rostovceva), Pojarkovella nibelis (Durkina), Pojarkovella spp.

16. Pseudoendothyridae: Eoparastaffella? sp., Pseudoendothyra sublimis (Rauzer-Chernousova), P. bona Rozovskaya, $P$. kremenskensis Rozovskaya, P. ornata Brady, and P. nodus (Durkina).

17. Eostaffellidae: Eostaffella ex gr. radiata (Brady), Eostaffella ex gr. proikensis Rauzer-Chernousova, Eostaffella ex gr. ikensis Vissarionova, Eostaffella ex gr. mosquensis Vissarionova, Eostaffella ex gr. parastruvei RauzerChernousova, Millerella? sp., Zellerinella? sp.

\section{Manuscript received 6 May 2004 Manuscript accepted 1 December 2004}

\section{REFERENCES}

Aizenverg, D.E., Astakhova, T.V., Berchenko, O.I. et al. 1983. Late Serpukhovian substage in the Donets Basin (paleontological characteristics). Akademiya Nauk Ukrainskoi SSR, Institut Geologicheskikh Nauk, Kiev, 1-164 [in Russian].

Armstrong, A.K. \& Mamet, B.L. 1977. Carboniferous microfacies, microfossils, and corals, Lisburne Group, Arctic Alaska. US Geological Survey, Professional Paper, 849: 1-144.

Brenckle, P.L. \& Grelecki, C.J. 1993. Type Archaediscacean foraminifers (Carboniferous) from the former Soviet Union and Great Britain. Special Publication of the Cushman Foundation for Foraminiferal Research, 30: 1-58.

Brenckle, P.L., Ramsbottom, W.H.C. \& Marchant, T.R. 1987. Taxonomy and classification of Carboniferous Archaediscean foraminifers. Courier Forschungs-Institut Senckenberg, 98: 11-24.

Burgess, I.C. \& Mitchell, M. 1976. Viséan Lower Yoredale Limestones on the Alston and Askrigg Blocks, and the base of the D2 Zone in Northern England. Proceedings of the Yorkshire Geological Society, 40: 613-630.

Conil, R., Longerstaey, P.J. \& Ramsbottom, W.H.C. 1980. Matériaux pour l'étude micropaléontologique du Dinantien de Grande-Bretagne. Mémoires de l'Institut de Géologie de l'Université de Louvain, 30: 1-187.

Conil, R., Groessens, E., Laloux, M., Poty, E. \& Tourneur, F. 1991. Carboniferous guide foraminifera, corals and conodonts in the Franco-Belgian and Campine basins. Their potential for widespread correlation. Courier Forschungs-Institut Senckenberg, 130: 15-30.

Cózar, P. 2002. Taxonomic value of the diaphanotheca/luminotheca in the classification of Lower Carboniferous endothyroid Foraminiferida; creation of two new species of Pojarkovella. Geobios, 35 (3): 283-291.

Cózar, P. 2003. Foraminiferal fauna and zonation from the Early Carboniferous of Guadiato Area (SW Spain): comparison with European and North African foraminiferal zonal schemes and its palaeobiogeographical implications. In: Ahr, W.M., Harris, P.M., Morgan, W.A. \& Somerville, I.D. (Eds), Permo-Carboniferous carbonate platforms and reefs. Society of Economic Paleontologists and Mineralogists, Special Publication, 78 \& American Association of Petroleum Geologists Memoir, 83: 155-169.

Cózar, P. \& Somerville, I.D. 2004. New algal and foraminiferal assemblages and evidence for the recognition of the AsbianBrigantian boundary in northern England. Proceedings of the Yorkshire Geological Society, 55 (1): 43-65.

Cózar, P. \& Somerville, I.D. 2005a. Late Viséan calcareous algal assemblages in South-eastern Ireland. Neues Jahrbuch für Geologie und Paläontologie Monatshefte, 2004 (12).

Cózar, P. \& Somerville, I.D. 2005b. Stratigraphy of upper Viséan carbonate platform rocks in the Carlow district, southeast Ireland. Geological Journal, 40 (1): 35-64.

Cózar, P. \& Vachard, D. 2001. Dainellinae subfam. nov. (Foraminiferida du Carbonifère inférieur), révision et nouveaux taxons. Geobios, 34 (5): 505-526.

Fewtrell, M.D., Ramsbottom, W.H.C. \& Strank, A.R.E. 1981. Carboniferous. In: Jenkins, D.G. \& Murray, J.W. (Eds), Stratigraphical atlas of fossil Foraminifera. British Micropalaeontological Society, Ellis Harwood, Chichester, 13-69.

Gallagher, S.J. 1992. Lithostratigraphy, biostratigraphy and palaeoecology of upper Dinantian platform carbonates in parts of southern and western Ireland. $\mathrm{PhD}$ thesis. National University of Ireland, vol. I, 312p., vol. II, 191p.

Gallagher, S.J. 1996. The stratigraphy and cyclicity of the late Dinantian platform carbonates in parts of southern and western Ireland. In: Strogen, P., Somerville, I.D. \& Jones, G.Ll. (Eds), Recent Advances in Lower Carboniferous Geology. Geological Society, London, Special Publications, 107: 239-251.

Gallagher, S.J. \& Somerville, I.D. 1997. Late Dinantian (Lower Carboniferous) platform carbonate stratigraphy of the Buttevant area North Co., Cork, Ireland. Geological Journal, 32: 313-335.

Gallagher, S.J. \& Somerville, I.D. 2003. Lower Carboniferous (Late Viséan) platform development and cyclicity in southern Ireland: Foraminiferal biofacies and lithofacies evidence. Rivista Italiana di Paleontologia e Stratigrafia, 109 (2): 152-165.

George, T.N., Johnson, G.A.L., Mitchell, M., Prentice, J.E., Ramsbottom, W.H.C., Sevastopulo, G.D. \& Wilson, R.B. 1976. A correlation of Dinantian rocks in the British Isles. Geological Society, London, Special Reports, 7: 1-87.

Groves, J.R. 1983. Calcareous foraminifers and algae from the type Morrowan (Lower Pennsylvanian) region of Northeastern Oklahoma and Northwestern Arkansas. Oklahoma Geological Survey, Bulletin, 133: $1-63$.

Groves, J.R. 1988. Calcareous foraminifers from the Bashkirian stratotype (Middle Carboniferous, South Urals) and their significance for intercontinental correlations. Journal of Paleontology, 62 (3): 368-399.

Hallett, D. 1971. Foraminifera and algae from the Yoredale 'series' (Viséan-Namurian) of Northern England. Compte Rendu du 6 ème Congrès International de Stratigraphie du Carbonifère, 3. University of Sheffield, Sheffield 1967, 873-901.

Johnson, G.A.L. \& Nudds, J.R. 1996. Carboniferous biostratigraphy of the Rookhope Borehole, Co. Durham. Transactions of the Royal Society of Edinburgh, Earth Sciences, 86: 181-226.

Jones, G.Ll. \& Somerville, I.D. 1996. Irish Dinantian biostratigraphy: practical applications. In: Strogen, P., Somerville, I.D. \& Jones, G.Ll. (Eds), Recent Advances in Lower Carboniferous Geology. Geological Society, London, Special Publications, 107: 371-385.

Laloux, M. 1988. Foraminifères du Viséen Supérieur et du Namurien du Bassin franco-belge. In: stratotypes carbonifères et devoniens en Belgique. Livret-guide. Bulletin de la Société Belge de Géologie, 96(3): 205-220.

Loeblich, A.R. \& Tappan, H. 1988. Foraminiferal genera and their classification. Van Nostrand Reinhold Company, New York, $970 \mathrm{pp}$.

Mamet, B.L. 1974a. Taxonomic note on Carboniferous Endothyracea. Journal of Foraminiferal Research, 4 (4): 200-204.

Mamet, B.L. 1974b. Une zonation par foraminifères du Carbonifère inférieur de la Téthys occidentale. Comptes Rendus 7ème Congrès International de Stratigraphie et de Géologie du Carbonifère, 3: 391.

Mamet, B.L., Pinard, S. \& Armstrong, A.K. 1993. Micropaleontological Zonation (Foraminifers, Algae) and Stratigraphy, Carboniferous 
Peratrovich Formation, Southeastern Alaska. US Geological Survey Bulletin, 2031: 1-64.

Pinard, S. \& Mamet, B.L. 1998. Taxonomie de petits foraminifère du Carbonifère supérieur-Permien inférieur du bassin de Sverdrup, Arctique canadien. Palaeontographica Canadiana, 15: 1-225.

Pirlet, H. \& Conil, R. 1977. L'évolution des Archaediscidae viséens. Bulletin de la Société belge de Géologie, Paléontologie et d'Hydrologie, 82 (2 (for 1973)): 241-299.

Ramsbottom, W.H.C. (Ed.) 1981. Field guide to the boundary stratotypes of the Carboniferous stages in Britain (Leeds, 25 August-1st September 1981). IUGS Subcommission on Carboniferous Stratigraphy, 110pp.

Rauzer-Chernousova, D.M., Bensh, F.R., Vdovenko, M.V. et al. 1996. On the systematics of Paleozoic foraminifera (Endothyroida, Fusulinoida). Nauka, Moscow, 1-204 [in Russian].

Reitlinger, E.A. 1981. On the systematization of Endothyroidea. Voprosii Mikropaleontologii, 24: 43-59 [in Russian].

Somerville, H.E.A. 1999. Conodont biostratigraphy and biofacies of Upper Viséan rocks in parts of Ireland. $\mathrm{PhD}$ thesis. University College Dublin. Vol. I, 290 pp; Vol. II, 228 pp.

Somerville, I.D., Strogen, P. \& Jones, G.Ll. 1992. Biostratigraphy of Dinantian limestones and associated volcanic rocks in the Limerick Syncline, Ireland. Geological Journal, 27: 201-220.

Strank, A.R.E. 1981. Foraminiferal biostratigraphy of the Holkerian, Asbian and Brigantian stages of the British Lower Carboniferous. PhD thesis. University of Manchester, 391pp.
Tietzch-Tyler, D., Sleeman, A.G., McConnell, B.J. et al. 1994. Geology of Carlow-Wexford. In: McConnell, B. (Ed.), A geological description to accompany the Bedrock Geology 1:100,000 Scale Map Series, Sheet 19, Carlow-Wexford. Geological Survey of Ireland, Dublin, 1-56.

Vachard, D. 1977. Etude stratigraphique et micropaléontologique (algues et foraminifères) du Viséen de la Montagne Noire (Hérault, France). Mémoires de l'Institut de Géologie de l'Université de Louvain, 29: 111-195.

Vachard, D. 1988. Pour une classification raisonnée et raisonable des Archaediscidae (Foraminifera, Carbonifère Inférieur-Moyen). Benthos'86, Third International Symposium on Benthic Foraminifera, Genève. Revue de Paleobiologie, Special Publication, 2: 103-123.

Vachard, D. \& Beckary, S. 1991. Algues et foraminifères bachkiriens des Coal Balls de la Mine Rosario (Truebano, León, Espagne). Revue de Paléobiologie, 10 (2): 315-357.

Vachard, D. \& Maslov, A. 1996. Précisions biostratigraphiques et micropaléontologiques sur le Bashkirien d'Ukraine (Carbonifère moyen). Revue de Paléobiologie, 15 (2): 357-383.

Zaninetti, L. \& Altiner, D. 1979. La famille des Archaediscidae (foraminifères): Analyse taxonómique et propositions pour une nouvelle subdivision. Archives des Sciences, Genève, 32 (2): 163-175. 